\title{
Farming economies in Ukraine by resource potential aggregate
}

\author{
Valeriy Rudenko*, Myroslav Zayachuk, Zhanna Buchko, \\ Hanna Ieremiia
}

Chernivtsi Yuriy Fedkovych, National University, Ukraine

This paper is aiming to present the concept of 'resource potential aggregate of farming economies' and trial an analysis of agriculture development units based on it. The resource potential aggregate takes into consideration the following: interconnected labour, materials and land resources. As a whole functioning mechanism, they predefine the perspectives of their own development objectively and determine its level. Quantitative estimations, such as costs (to start with) related to the economies of the farming associations, land use structure and territorial productivity, have been disclosed as methodological specificities concerning the value of resource potential aggregate. It is asserted that land resources play the leading role in the structure of resource potential aggregate (over $76 \%$ ). They are followed by capital assets (nearly 15\%), and labour resources (nearly 9\%). The 'Prychornomorskyy', the 'Prydniprovskyy' and the Central economic units known as 'rayons' are characterised as keepers of the highest resource potential aggregate of economies of farming associations. NorthWestern and the Carpathian rayons show the lowest values. Meanwhile, the highest territorial productivity of resource potential aggregate is to be noticed in the economies of farming associations of Podilskyy, Carpathian and Stolychnyy rayons in Ukraine.

Key Words: resource potential aggregate, farming economies, farming association.

Article Info: Received: March 2, 2017; Final revision: November 8, 2017; Accepted: November 15, 2017; Online: November 25, 2017.

\section{Introduction}

Radical agrarian reforms in Ukraine (the 1990s - early 2000s) have led to deep social-economic transformations that resulted in the fundamental reorganisation

* Corresponding author

Address: Faculty of Geography, Chernivtsi Yuriy Fedkovych National University, 2 Kobylianskoyi Str., Chernivtsi, 58012, Ukraine.

Phone: (+38 0372)584854 | Email: rudenko_valery@ukr.net

(C)2017 Human Geographies; The authors

(c) (1) This work is licensed under a

Creative Commons Attribution 4.0 International License. DOI:10.5719/hgeo.2017.112.7 
of rural production relations and those between different agricultural sectors. Moreover, the formation of new agrarian economics based on market principles of management gave birth to private ownership of land resources and means of production, as well as introduced new organisational-legal forms of management, inclusive of patterns of farming.

All these changes require scientific analysis and synthesis, particularly from the standpoint of social geography. The nation-scale and regional socialgeographic research into formation of different agricultural patterns with accentuation on land use specificities; formation of basic production assets; effects of different natural and social-economic factors on agricultural activity; labor resource management and employment specificities in agricultural production; territorial concentration of production of major agricultural goods; food market commoditization, etc, seems to be of essential importance.

If three major agricultural producers, namely, collective, individual and farming economies (associations) are considered, it is the latter that are regarded to be able to solve the majority of rural social problems and strengthen their platform in the food market. The farming association is a form of entrepreneurial activity with the formation of legal entity undertook by individuals who declared their willingness to produce commercial yield, process it and sell to have profit within land areas entitled to them for the purpose of farming (Statistical Yearbook, 2013, p. 122).

It is now about 41,000 active farming associations in Ukraine which cultivate $12 \%$ of Ukrainian agricultural lands entitled to them, and produce nearly $3 \%$ of the gross agricultural product's cost within the country. Though still insignificant, the share of production by farms of major crops tends to grow; for example, they provide for $20 \%$ of the cropping of buckwheat, millet and beet. The farmers' role in the provision of animal products is still less making nearly $3 \%$ of wool, $2 \%$ of meat, $1 \%$ of milk, and $0,5 \%$ of eggs (Zayachuk, 2013, p. 81). At the same time, due to the comparatively young age of this form of entrepreneurship in Ukraine, a number of questions require their urgent and scientifically substantiated solution; among these - the problem of the effective use of the whole complex of nature, labour and material resources in farming.

Efficient analysis of the attained level of development; disclosure of latent reserves; substantiation of directions to help form national and regional socialterritorial complexes; evaluation of their (complexes) production potential; realization of principles of regional self-support and self-financing; estimation of quantitative parameters of the resources' interaction and replaceability, and the rates of their use; informational provision of educational-cognitive activity require the reduction of different-type resources within national economy to a single generalized index of resource potential aggregate. We mean such index that would combine the interconnected labour, material and nature resources that characterize in their totality the perspectives of the objectively conditioned level of development of farming associations in Ukraine. Proceeding from the above, the quantitative (in the first place - cost) estimation of resource potential aggregate of Ukrainian farming associations in present-day conditions of their development represent the goal of this study. 


\section{Methodology}

The issue of commeneurability, or combination of heterogeneous resources into a single index was repeatedly considered in the works by Strumilin (1963), Cloke \& Park (1985), Lee \& George (2002), etc.

In the process of development of methodical bases that would be helpful in establishing the integral index of national economy's resource potential aggregate, we have outlined three major trends that base on the use of the index method, the regression models and the cost estimation of labour, material and nature resources.

However, when it comes to calculations of resource potential aggregate, our experience says that the capacities of the index and the regression methods are rather restricted. Paskhaver has demonstratively proved that, on the one hand, the same as with all other methods of variation statistics, the regression analysis estimates the factor's contribution into variation of the resultative parameter around the mean level but not into it; on the other - the regression estimates shall be valid only within the limits of population covered by one model. The resources' regression estimates thus distort economic proportion of production resources; they are exceptionally unstable in both temporal and territorial aspects (Paskhaver, 1982, pp. 182-183).

We believe that the cost estimation of labour, material and nature resources has proved to be the most reliable method. The cost of the commodity is determined by social labour materialized in the said commodity. Money is the standard of value. Hence, monetary estimations are as well labour estimations. Strumilin, the pioneer of integral estimations of the country's production potential, was the first who suggested methods and calculated in money equivalent the labour and nature resources (Strumilin, 1963, pp. 184, 296). The appropriateness of summing up the living and materialised labour in pieces of money finds no doubt with the majority of those involved in the problem (Strumilin, 1963, Rudenko \& Rudenko, 2011).

Let us consider methodical specificities of such estimation on the whole and each component of potential aggregate in particular. To begin with, we cannot but emphasise that the present article deals with the resource potential in its annual dimension, that is, we do not define the 'capital', but the current estimate of the potential aggregate of farming associations. This estimate's importance in economic analyses was substantiated in a great number of works. In particular, in calculations of the efficiency of the national economy, it is essentially important to define the value of average annual resources. The comparison of average annual natural-material and labour resources and the physical scope of net production of the society would answer the question of how efficiently the production resources are used.

When we assess the resource potential aggregate economically, it is undoubtedly important to consider the factor of time. However, we believe this factor to be a separate problem that needs additional and still deeper development. Besides, further substantiation (suggested by a number of authors) is needed with respect to the discount level proper, that is, to pay for the use (or the possession) of the resource through time. The cost estimation will cover labour resources, capital assets, and land potential of farming associations of Ukraine. 
Cost estimation of labour resources within the resource potential aggregate is still insufficiently developed. Among the scope of methodical approaches, we would outline the one where the embodied and direct labour is harmonised through estimation of production assets in man-years. For this purpose, the cost of production assets should be divided by the worker's average annual productivity in the process of creation of national income.

Another currently and intensely developed idea lies in the estimation of the unit of living labour by a single average annual worker by way of the establishment of its (unit) fund analogue. This suggestion originates from references to interchangeability (to some extent) of the living and the embodied labour. When the marginal efficiency of capital assets approaches its mean value, the values of the fund analogue shall be measured by way of division of the worker's annual costs of wages by the normative coefficient of the efficiency of investments. According to Paskhaver, 'formally, the division of the wages fund by the normative coefficient of the efficiency of investments provides for 'capitalisation' of wages as a type of current expenses and thus allows for the transition from resource to the current estimation of the labour factor' (Paskhaver 1982, p. 218). With that, the scientist warns that the resource estimation of labour factor should not be understood as 'capital' estimation of labour resources proper, but as the establishment of the number of tangible assets that are capable of freeing the estimated labour resources.

The worker's annual wages are therefore the indicator of the current fundsubstitutive estimate of labour resources or their estimate in yearly dimension, and this is what we proceed from in this work when assessing resource potential aggregate of Ukrainian farming economies.

Consequently, the estimation of labour resources of Ukrainian farming associations is characterised by annual nominal wages of its workers in 2011 2013 (Agriculture, 2014, P. 235). The potential of labour resources calculated on this basis will thus amount to UAH 2,427 milliards, or USD 0,304 milliards.

Besides labour and nature resources, capital and current assets stay to be among the most important preconditions of and factors for social-economic development. No product would ever be manufactured without them. This is why the obtained effect should not be referred only to current, but also to nonrecurring costs invested into active assets created within the whole previous period. And, since nonrecurring costs cannot be summed up with current costs due to different time of their turnover and actually different dimensionality, the nonrecurring costs should be reduced to annual dimension (to be compared to other resources) by way of finding the percentage of the active production assets and the stock in accordance with pre-established standard of efficiency $(0,15)$.

Let the value of all applied advance assets equals $\mathrm{F}$, and the efficiency ratio $\mathrm{E}$, then, after reduction of assets to the annual dimension we shall have EF. Economically, such product can be interpreted as follows: it is the amount which the enterprise would have debited to a bank (besides current expenses and profit) in case that the money needful for putting the enterprise into operation should have been taken from this bank proceeding from payment of annual interest equal to standard of efficiency. At the same time, in a present-day situation with the development of farming associations in Ukraine, the total stock of fixed assets involved into farming can be estimated (due to the absence 
of appropriate information) solely by way of expert assessment. Agricultural machinery available in farming associations of the state in 2011-2013 (tractors, harvester-threshers, maize harvesters, forage harvesters, seeding machines, windrowers, etc. (Agriculture, 2014) was taken as a basis. Reduction of one time (capital) costs to a yearly dimension (to be comparable with the other resources) was conducted by way of percentage of active basic production assets in accordance with established standards of their efficiency $(0,15)$. The potential of capital assets of farming associations of Ukraine thus amounts to UAH 4,03 milliard (USD 0,505 milliard).

Land resources are the third important component of resource aggregate that in a most direct way effect on the scale and the level of farming development. Lands are in the first place the primary means of the agrarians' production activity. It is necessary to note that farmers in each specific case, depending on availability of free lands, natural conditions (on which the average land share size depends) and generally formed structure of land use were given land areas of different size and quality. It is well-known that a payable plant-product economy can be organized within huge land areas (over 300 ha depending on the farming pattern). Here we shall also note that a clear trend was observed as to the average farming associations' growth from 21 ha in 1995 to 120 ha in 2015. Nonetheless, there exist considerable territorial differences: the smallest allotments are found in farms of the Carpathian Rayon, while the biggest - in the North-Eastern and Central economic rayons.

We have attempted to establish whether there exists a linear correlation between the value of land potential and the area of agricultural lands afforded to farming associations. The resulting correspondence $(K=+0,628)$ on a national level confirms the presence of such linear relationship. That is, availability of powerful land potential is to a great extent a precondition for affording bigger land areas to farmers. With that, the pre-formed structure of land use (from the point of view of functioning patterns) that features regional specificities is a significantly corrective factor. On the level of regions, no such linear relationship was found in the Autonomous Republic of Crimea, Cherkasy, Khmelnytskyy, Kharkiv, Poltava, Mykolayiv and Dnipropetrovsk oblasts ( $\mathrm{K}<$ $0,25)$, while all other regions show linear correlation with strong level of it in the Zakarpattia (+0.968), Ivano-Frankivsk (+0.822), Chernivtsi $(+0.752)$ and Lviv $(+0.713)$ oblasts of the Carpathian Economic Rayon. It should be noted that the above-stated regions represent an essential number of private landowners and land shares (and, correspondingly, weak preconditions to form big agroholdings) that were the basis for the development of farming.

The presence of the linear relationships between the value of land potential and the agricultural output by farming associations to some extent demonstrates the former's intense and efficient use. Total linear correlation in Ukraine amounts to $+0,613$ and is confirmed in the Ternopil, Chernivtsi, Kirovograd, Ivano-Frankivsk, Dnipropetrovsk, Lugansk and Zhytomyr oblasts. Among these, there are regions with land-poor farming associations which try to the greatest possible extent intensely use their land areas (Chernivtsi, Ivano-Frankivsk, Ternopil, Zhytomyr oblasts), and the regions with the dominance of sectorspecific farming economies (those basically growing technical and cereal crops). We can not but agree with explorers of this problem who regard the land poten- 
tial of the territory (water area) as an entity strongly inertial and relatively stable in its quantitative and qualitative development. Proceeding from the above, no natural national-scale re-valuation of land resources is made more often than once a ten or twenty years. The economic estimation of all agricultural lands of Ukraine was for the last time conducted as far back as in 1987-1988 with none subsequent estimations. A similar situation is with mineral, water and forest resources. On the one hand, such labour-consuming and broad-scale operation will require huge finances; on the other, if the aforesaid inertia of land resources is considered, there is no imperative need for such estimation (Rudenko and Rudenko, 2011).

With regard to the above, the present-day resource explorers focus their efforts on the problem of indexation of land resource cadastre assessments conducted in the late 1980-1990s. Particular attention in this respect deserves the Price of Land by Academician Yukhnovskyy \& Loboda, Candidate of Economic Sciences (2002). The authors' dominant idea (which is very important in conditions of unstable economics) is that 'the natural yielding capacity of Ukrainian lands, i.e. such capacity achieved by adhering to crop rotation and only mechanical soil cultivation with no fertilisation should be taken as an assessment standard'. Proceeding from calculations made at the Soil Science and Agro-Chemistry Institute of the Ukrainian Academy of Agricultural Sciences and guided by their materials, as well as those available with the Institute of Agrarian Economics of the same, Yukhnovskyy \& Loboda have established that the present-day price of arable land should amount to $\$ 3810 /$ ha. With Ukrainian economics' average normative coefficient of capital investments' efficiency of 0.15 , the value of the land potential of farming associations in this country in yearly proportion will amount to UAH20,953 milliard, or USD2,624 milliard (Tables 1-2, Figure 1).

As to specificities of farmers' land use, we can not but note as follows: firstly, the farmers in the majority of cases were given lands residually, and these were not of the best quality; secondly, the conditions of farming association management (rent and credit payments) make farmers maximally and sometimes exhaustively exploit agricultural lands; thirdly, the production-territorial type and sub-type of specialization chosen by the farmer play the decisive role in the land use.

\section{Study results}

Resource potential aggregate of farming associations of Ukraine was estimated as a sum of potentials of labour resources, capital assets and land resources. From 2011 to 2013 it amounted to UAH 27,41 milliard, or USD 3,433 milliard (Table 1). It is $76,4 \%$ of land resources in the component structure of the resource potential aggregate, these followed by capital assets (14,7\%), and labour resources $8,9 \%$ (Table 2). When economic rayons of Ukraine are dealt with, the Prychornomorskyy Rayon possesses the highest value of resource potential aggregate (24,7\%). It is followed by the Prydniprovskyy Rayon (15,5\%), the Central Rayon (13,5\%), the Podilskyy Rayon (13,2\%), and the North-Eastern Rayon (12,9\%). 
Table 1. Aggregate resource potential of farming economies of Ukraine

\begin{tabular}{|c|c|c|c|c|c|}
\hline \multirow[b]{2}{*}{$\begin{array}{c}\text { Republic, } \\
\text { Oblast }\end{array}$} & \multicolumn{4}{|c|}{$\begin{array}{c}\text { Aggregate resource potential, numerator } \\
\text { - million hryvnias, denominator - million USD }\end{array}$} & \multirow{2}{*}{$\begin{array}{c}\text { Oblast's } \\
\text { share in the } \\
\text { state's } \\
\text { potential }\end{array}$} \\
\hline & total & $\begin{array}{l}\text { labor } \\
\text { resources }\end{array}$ & $\begin{array}{l}\text { capital } \\
\text { assets }\end{array}$ & lands & \\
\hline Ukraine & $\frac{27410,0}{3433,0}$ & $\frac{2427,0}{304,0}$ & $\frac{4030,0}{504,7}$ & $\frac{20953,0}{2624,3}$ & 100,0 \\
\hline Donetsk & 1253,6 & 111,5 & 170,4 & 971,7 & 4,6 \\
\hline Lugansk & 1056,2 & 96,8 & 214,0 & 745,4 & 3,6 \\
\hline Dnipropetrovsk & 2563,2 & 230,9 & 446,4 & 1885,9 & 9,0 \\
\hline Zaporizhzhia & 1776,5 & 143,3 & 264,5 & 1368,7 & 6,5 \\
\hline Poltava & 1461,2 & 131,8 & 229,2 & 1100,2 & 5,3 \\
\hline Sumy & 659,0 & 58,6 & 103,2 & 497,2 & 2,4 \\
\hline Kharkiv & 1422,5 & 114,9 & 221,7 & 1085,9 & 5,2 \\
\hline Zhytomyr & 406,0 & 44,8 & 68,1 & 293,1 & 1,4 \\
\hline Kyiv & 1128,2 & 110,5 & 153,8 & 863,9 & 4,1 \\
\hline Chemigiv & 547,9 & 48,5 & 74,2 & 425,2 & 2,0 \\
\hline Kirovograd & 2488,0 & 182,1 & 377,6 & 1928,3 & 9,2 \\
\hline Cherkasy & 1169,2 & 108,2 & 157,3 & 903,7 & 4,3 \\
\hline $\begin{array}{c}\text { Autonomous } \\
\text { Republic of Crimea }\end{array}$ & 935,9 & 69,9 & 70,3 & 795,7 & 3,8 \\
\hline Mykolayiv & 1927,4 & 181,7 & 255,2 & 1490,5 & 7,1 \\
\hline Odesa & 2168,3 & 155,4 & 268,9 & 1744,0 & 8,2 \\
\hline Kherson & 1462,5 & 135,8 & 159,5 & 1167,2 & 5,6 \\
\hline Vinnytsia & 1915,3 & 152,8 & 261,4 & 1501,1 & 7,2 \\
\hline Temopil & 635,0 & 39,3 & 65,4 & 530,3 & 2,5 \\
\hline Khmelnytskyy & 939,9 & 85,6 & 131,2 & 723,1 & 3,5 \\
\hline Volyn & 275,8 & 31,8 & 64,3 & 179,7 & 0,9 \\
\hline Rivne & 258,8 & 29,1 & 65,1 & 164,6 & 0,8 \\
\hline Zakarpattia & 116,1 & 33,7 & 26,0 & 56,4 & 0,3 \\
\hline Lviv & 382,3 & 65,2 & 99,6 & 217,5 & 1,0 \\
\hline Ivano-Frankivsk & 187,2 & 27,9 & 41,8 & 117,5 & 0,6 \\
\hline Chemivtsi & 274,0 & 36,9 & 40,9 & 196,2 & 0,9 \\
\hline
\end{tabular}

The lowest such potential is observed in the North-Western Rayon (1,7\%), and the Carpathian Rayon (2,8\%). On the level of administrative units, the highest share in the resource potential aggregate is enjoined by the Kirovograd, Dnipropetrovsk, Odesa, Vinnytsia and Mykolayiv Oblasts (over 40\%), while the lowest (less than $1 \%$ ) is observed in the Zakarpattia, Ivano-Frankivsk, Rivne, Volyn and Chernivtsi administrative oblasts. Such distribution is determined by such component of potential aggregate as land resources.

It is interesting to trace territorial differences between economic rayons of Ukraine with respect to the distribution of resource potential aggregate's components. For example, the share of the potential of labour resources ranges from $17,1 \%$ in the Carpathian Rayon ( $\max$ ) to $7,9 \%$ in the Central (min). At the same time, if absolute values are regarded, the Prychornomorskyy, the NorthEastern, the Prydniprovskyy, and the Podilskiy economic rayons (over UAH 250 million each) would capture the primacy. Among administrative oblasts, the absolute leadership is with the Dnipropetrovsk Oblast (UAH 230,9 million). As to the share of labour resources within the potential aggregate of farming associations in administrative oblasts, it should be noted that it is close to an 
Table 2. Components structure of aggregate resource potential in farming economies of Ukraine

\begin{tabular}{|c|c|c|c|}
\hline \multirow{2}{*}{ Republic, Oblast } & \multicolumn{3}{|c|}{ Potential of resources, \% } \\
\hline & labor & capital assets & lands \\
\hline Ukraine & 8,9 & 14,7 & 76,4 \\
\hline Donetsk & 8,9 & 13,6 & 77,5 \\
\hline Lugansk & 9,2 & 20,3 & 70,5 \\
\hline Dnipropetrovsk & 9,0 & 17,4 & 73,6 \\
\hline Zaporizhzhia & 9,1 & 14,9 & 76,0 \\
\hline Poltava & 9,0 & 15,7 & 75,3 \\
\hline Sumy & 8,9 & 15,7 & 75,4 \\
\hline Kharkiv & 8,1 & 15,6 & 76,3 \\
\hline Zhytomyr & 11,0 & 16,8 & 72,2 \\
\hline Kyiv & 9,8 & 13,6 & 76,6 \\
\hline Chemigiv & 8,9 & 13,5 & 77,6 \\
\hline Kirovograd & 7,3 & 15,2 & 77,5 \\
\hline Cherkasy & 9,3 & 13,5 & 77,2 \\
\hline Autonomous Republic of Crimea & 7,5 & 7,5 & 85,0 \\
\hline Mykolayiv & 9,4 & 13,2 & 77,4 \\
\hline Odesa & 7,2 & 12,4 & 80,4 \\
\hline Kherson & 9,3 & 10,9 & 79,8 \\
\hline Vinnytsia & 6,2 & 10,3 & 83,5 \\
\hline Temopil & 9,1 & 14,0 & 76,9 \\
\hline Khmelnytskyy & 8,0 & 13,6 & 78,4 \\
\hline Volyn & 11,5 & 23,3 & 65,2 \\
\hline Rivne & 11,2 & 25,2 & 63,6 \\
\hline Zakarpattia & 29,0 & 22,4 & 48,6 \\
\hline Lviv & 17,1 & 26,1 & 56,8 \\
\hline Ivano-Frankivsk & 14,9 & 22,3 & 62,8 \\
\hline Chemivtsi & 13,5 & 14,9 & 71,6 \\
\hline
\end{tabular}

average nation-scale value in the majority of the oblasts which ranges from 8,0 to $9,5 \%$. The western oblasts of Ukraine - Zakarpattia, Lviv, Ivano-Frankivsk, Chernivtsi, Volyn and Rivne - are the exceptions featuring land-poor farming with a predominance of stoop labour. The highest share of the potential of capital assets is observed in the North-Western Rayon (24,2\%), and the lowest $(11,6 \%)$ - in the Prychornomorskyy Rayon. With respect to absolute values, the Prychornomorskyy, Prydniprovskyy, North-Eastern and Central economic rayons take leadership concentrating $63,4 \%$ of the national potential of farming capital assets. The maximal potential of capital assets is available in the Dnipropetrovsk Oblast. With an average national share of capital assets within the structure of resource potential aggregate amounting to $15 \%$, a slightly bigger value is observed in the Lviv, Ivano-Frankivsk, Zakarpattia and Lugansk Oblasts.

Specific weight of the potential of land resources reaches its maximum in the Prychornomorskyy Rayon (80,0\%), while the minimum $(61,2 \%)$ is observed in the Carpathian Rayon. In absolute values, the biggest land potential is observed in farming associations of the Prychornomorskyy, Prydniprovskyy, Central, Podilskiy and North-Eastern economic rayons, totally amounting to $80 \%$ of national-scale land potential developed by farming associations. Concerning 


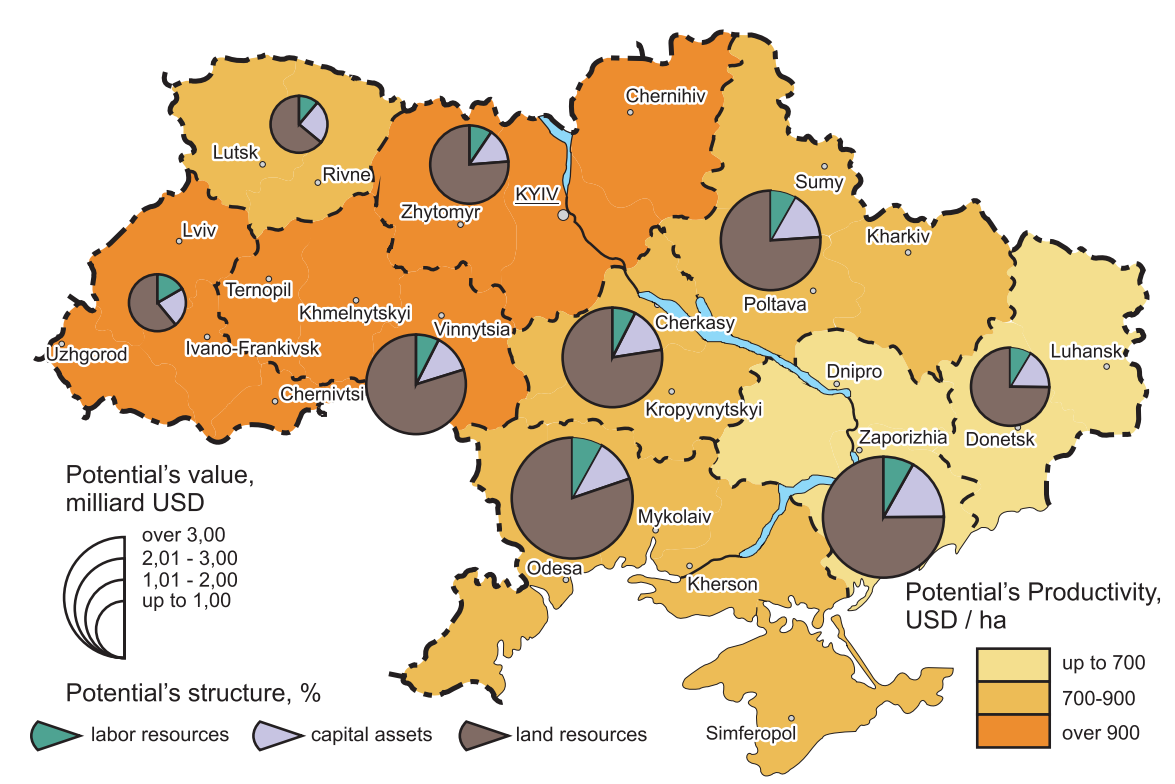

Figure 1. Aggregate Resource Potential of Farming Economies in Economic Rayons of Ukraine

administrative oblasts, the Kirovograd, Dnipropetrovsk and Odesa oblasts take firm leadership. Land resources form the basis of the resource potential aggregate of farming associations (over $75 \%$ on a national scale), and their share is dominant in almost all regions ranging from $49 \%$ in the Zakarpattia Oblast to $85 \%$ in the Autonomous Republic of Crimea.

It is also important to trace the territorial productivity (return) of the resource potential aggregate of farming associations in Ukrainian economic rayons. The highest territorial productivity of resource potential aggregate is found with farming associations of the Podilskyy Rayon (UAH 8,3 thousand/ha, or USD 1037/ha), followed by the Carpathian (UAH 7,9 thousand/ha, or USD992/ha) and the Stolychnyy (UAH 7,2 thousand/ha, or USD 905/ha) rayons. The potential's lowest return is in farming associations of the Donetsk Rayon (UAH4,9 thousand/ha, or USD 617/ha), and the Prydniprovskyy Rayon (UAH 5,5 thousand/ha, or USD 683/ha).

\section{Conclusions}

The resource potential aggregate of Ukrainian farming associations covers interconnected labour, material and land resources that predefine the perspectives of reaching of the objectively conditioned level of said economies' development. It was estimated to amount to UAH 27,41 milliard, or USD 3,433 milliard on the annual (2011-2013) average.

The leading role in the structure of resource potential aggregate of Ukrainian farming associations belongs to the potential of land resources $76,4 \%$, this followed by the potentials of capital assets (14,7\%) and labour resources $(8,9 \%)$. The highest indices of territorial productivity of resource 
potential aggregate were observed in farming associations of the Podilskyy, Carpathian and Stolychnyy economic rayons, while the lowest - in the Donetsk and Prydniprovskyy rayons.

\section{References}

Cloke, P.J. and Park, C.C. (1985), Rural Resource Management, London \& Sydney, Croom Helm, pp. $1-475$.

Lee, N. and George, C. (2002), Environmental Assessment in Developing and Transitional Countries, New York, Wiley, pp. 1 - 290.

Paskhaver, B.Yo. (1982), Production Resources and Efficiency of Agriculture / Efficiency of Agricultural Nature Use, Kiev, Vedenichev \& N Dumka, pp. 174 227.

Rudenko, V., Zaiachuk, M. and Palamaruk, M. (2013), 'Nature-Resource Potential of the Carpathian Region of Ukraine and Specificities or its Use by Farming Enterprises', Natural Resources, no. 4, pp. 257 - 263.

Rudenko, V.P. and Rudenko, S.V. (2011), 'Revaluation of Nature-Resource Potential of Ukraine', Geography and Natural Resources, vol. 32, no. 1, pp. 95 97.

Statistical Yearbook of Ukraine (2014), State Service for Statistics, Kyiv, pp. 1 534.

Strumilin, S. (1963), Statistics and Economics, Selected Works, B 2 - XT, vol. 1, Academic Press, Academy of Sciences, USSR, pp. 1 - 488.

Ukrainian Agriculture in 2013, Statistical Reference Book 2014, Kyiv, State Service for Statistics, pp. $1-400$.

Yukhnovskyy, I. and Loboda, G. (2002), Price of Land, Courier of the Government, no. 105, Kyiv, p. 7.

Zayachuk, M. (2013), 'Geografical Particularities of Farming Formation in Ukraine’, Geographia Technica, no. 2, pp. 80-88. 